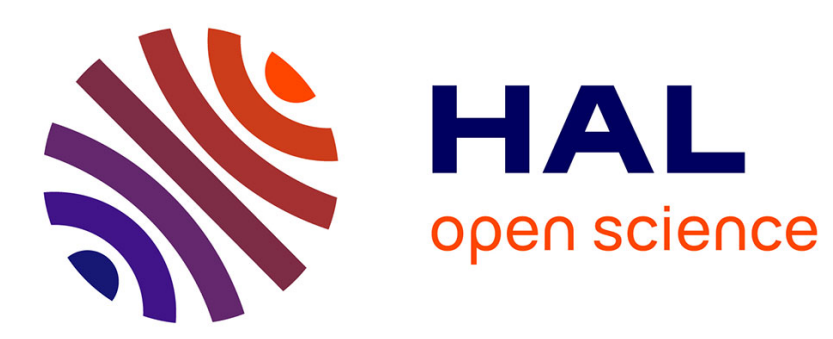

\title{
Economic appraisal of profitability and sustainability of peri-urban agriculture in Bangkok
}

\author{
Isabelle Vagneron
}

\section{To cite this version:}

Isabelle Vagneron. Economic appraisal of profitability and sustainability of peri-urban agriculture in Bangkok. Ecological Economics, 2007, 61 (2-3), pp.516-529. 10.1016/j.ecolecon.2006.04.006 . hal02666459

\section{HAL Id: hal-02666459 \\ https://hal.inrae.fr/hal-02666459}

Submitted on 31 May 2020

HAL is a multi-disciplinary open access archive for the deposit and dissemination of scientific research documents, whether they are published or not. The documents may come from teaching and research institutions in France or abroad, or from public or private research centers.
L'archive ouverte pluridisciplinaire HAL, est destinée au dépôt et à la diffusion de documents scientifiques de niveau recherche, publiés ou non, émanant des établissements d'enseignement et de recherche français ou étrangers, des laboratoires publics ou privés. 


\title{
Economic appraisal of profitability and sustainability of peri-urban agriculture in Bangkok
}

\author{
Isabelle Vagneron $^{1}$
}

\begin{abstract}
Promoters of urban and peri-urban agriculture generally stress its positive role in terms of food security, income, employment and improvement of the urban environment. Unfortunately, competition with agricultural and non-agricultural uses of peri-urban farm land often translates into intensive farming systems that are detrimental to the environment. Based on two original surveys of peri-urban farms in the area of Bangok, this paper ranks four cropping systems (fish, shrimp, rice, and fruits) according to their economic profitability. A second step of the analysis aims at taking into account the cost of water into the analysis, so as to assess whether the hierarchy formerly established is modified. Although all environmental costs are not introduced and environmental benefits are ignored, this work paves the way for further research in the area of taking into account the environmental impact of farming activities.
\end{abstract}

Keywords - environmental economics, peri-urban agriculture, Asia, Thailand.

\section{INTRODUCTION}

Peri-urban agriculture refers to farming activities - horticulture and crop production, animal husbandry, aquaculture and forestry - carried out within, or at the periphery of, the cities. These activities draw on a set of existing resources (land, water, labor, waste, energy, etc.) that can be used for either agricultural or non-agricultural uses, and generate food and non-food flows towards the urban centers (Moustier and Mbaye, 1999). They may be either exclusively oriented towards the market, or part of a household's strategy to meet its basic needs. Although peri-urban agriculture may be considered as a temporary activity (Van den Berg, 1984), its positive and lasting role has been highlighted (Mougeot, 1994) and is increasingly taken into account by policy-makers and urban planners around the world.

Indeed, peri-urban agriculture is encouraged in poor countries, mainly as a means of improving food security (Armar-Klemesu, 2000), by helping poor households cover an important share of their food consumption (thereby allowing them to save their money for other needs) and by improving the urban population's nutrition status (greater freshness of the products, better access to vegetables considered as a major source of vitamins and micro-nutrients). This is all the more true as inefficient transportation and storage facilities in most poor countries make it safer and less costly to locate the production of perishable products near the main consumption areas (Argenti, 2000). Thanks to the diversity of crops species and to low barriers to entry - low surface requirements, possibility of using vacant land, recycled waste, waste water - peri-urban agriculture is likely to provide jobs and incomes to various groups of city dwellers ${ }^{2}$, be they poor and landless urbanites, middle-income housewives, retired civil servants officers or wealthy farmers (Nugent, 2000). It must also be noted that urban and peri-urban agriculture may be carried out for other purposes (cultural, community involvement). The possibility of carrying out intensive production on small plots of land is often quite well adapted to the urban environment where water and land are scarce. Furthermore, the temporary leasing of urban land may optimize the use of vacant plots.

1 CIRAD, UR Normes et Marché, 73 rue Jean-François Breton TA40 / 15 - 34398 Montpellier Cedex 5, France. Tél. : (+33) 0467615710 - Fax.: (+33) 0467614415 - Email : isabelle.vagneron@cirad.fr

2 “There is no such person as the 'average urban farmer'. He or she may come from any portion of a city's population spectrum... Urban farmers include the wealthy and the poor, recent immigrants and landed gentry” (Smit and Nasr, 1996, p. 71). 
Finally, peri-urban agriculture may help recycle waste (Smit and Nasr, 1996) and provide an improved environment for city dwellers (less noise, water and air pollution, green areas).

However, peri-urban agriculture also suffers from its proximity to the city. The use of improperly treated waste water or solid waste and the contact with polluted air are risky for both consumers (through the contamination of food products) and producers (Birley and Lock, 1999). Moreover, peri-urban activities may be jeopardized by the highly uncertain environment in which they are undertaken (most farmers suffer the constant threat of losing the land over which they have no property rights). Finally, peri-urban activities may further aggravate existing pollution problems, through the excessive use of chemical products and the production of agriculture-related toxic waste (e.g. pesticide or fungicide residues). The final consequences of agriculture-induced pollution may be the contamination of drinking water resources and food products, the eutrophication of water systems, increased air pollution and the transmission of infectious diseases where livestock is involved.

The main objective of this paper is to assess the economic profitability of a number of agricultural systems located in the periphery of Bangkok and to balance the picture obtained by taking into account some of the environmental problems related to those systems, based on a survey of farmers. Peri-urban agriculture has been pictured as a potentially profitable activity, especially in Asia (Jansen et al., 1996; Midmore and Jansen, 2003), hence the idea to question this image in the case of Bangkok. The paper is organized as follows: section 2 introduces the challenges faced by peri-urban farms in the area of Bangkok and stresses the importance of water related issues. Section 3 presents the main features of the farms surveyed (size, yields, income, costs, etc.) and ranks them according to their level of profitability. Section 4 focuses on two major environmental issues faced by the farmers in the course of their activity, i.e. the quality of water and the use of chemical inputs. Section 5 summarizes the main results obtained and

\section{AREA OF STUDY, MATERIALS AND METHODS}

\section{Bangkok suburbia, a challenging environment for farming}

Bangkok has always concentrated Thailand's wealth. From the mid 1960s onwards, factories and the middle class started settling at the fringes of the city (Dixon, 1999). The share of the population engaged in agricultural activities inside Bangkok dropped dramatically. As the city grew, land was kept for speculation, while workers switched to industrial jobs. Since 1980, the provinces close to Bangkok have been growing faster than Bangkok itself. Soaring land prices and wage rates and aggravated traffic problems have pushed the industries to the fringes of the capital. This expansion of the urban and industrial fabric towards the provinces has been both uncontrolled and uncoordinated: the lack of an official city plan until the early 90s translated into a chaotic pattern of land use, whereby residential houses are mixed with commercial buildings, factories and farms (Lo and Yeung, 1996). The city's built-up area mushroomed from $67 \mathrm{~km}^{2}$ in the late 1950s to $426 \mathrm{~km}^{2}$ in the early 1990s (Falkus, 1993). During the 1990s, Bangkok continued to expand in a fairly uncontrolled way: urban concentration and regional urbanization led to very high growth and to the emergence of complex patterns of land use, commodity flows, population flows and life-styles. This evolution went hand in hand with a high pace of industrial and urban growth, the proliferation of motorized vehicles and uncontrolled development, resulting in numerous conflicts. As a consequence, both the population and the total area of cultivated land and the size of farms and plots have been declining in the southern part of the delta since the 1960s. The extent of such decline is greater the closer the area is to Bangkok. Within urbanized areas, the concentration of farm land along canals enables an easy access to free surface water for irrigation and transportation. The decline of agricultural activities within the Bangkok Metropolitan Area (BMA) can be explained by the fact that land is used for speculation, rather than for agricultural purposes ${ }^{3}$ : around

3 Inside Bangkok, many plots of land are kept for speculative purposes because the system of property or land taxes is too weak to have any deterrent effect. However, farming activities can be carried out on land saved for speculative motives (Lo and Yeung, 1996). 
Bangkok, land prices are much higher than anywhere else in the delta, inducing dramatic changes in the organization of space.

The Chao Phraya delta covers over 2 million hectares in Thailand's Central Plain and is crossed by four main water-ways connected together through a dense network of tributaries and canals. Bangkok is located in the southern part of this delta. In the Chao Phraya delta, the monsoon period extends from May to October. The average monthly and daily temperatures $\left(25^{\circ}-33^{\circ} \mathrm{C}\right)$ allow for year round rice cultivation, while the average rainfall reaches 900 to 1,400 mm/year (Adeel et al., 2002). The land is very flat in this area - the slope hardly ever exceeds $1 \%$ - inducing rural expansion to occur along artificial and existing canals used as irrigation, drainage and communication facilities. As a consequence of declining drainage conditions, the effect of the tide can be felt in the canals and rivers up to $60 \mathrm{~km}$ from the coast during the dry season, causing saline intrusions south of Bangkok and great damage to agriculture, while at the end of the rainy season, villages located in low-land areas east of Bangkok are likely to be flooded (Gillet and Ollivier, 2000). Conversely, water shortages during the dry season may cause the farmers to use reservoirs and pumps to bring water to the fields.

Is the "Venice of the East" drying out?

Once a water-abundant country, Thailand has lately been experiencing water shortages. Indeed, very rapid growth has triggered considerable demands for water. According to the World Bank ${ }^{4}$, water demand doubled between 1980 and 1990 and is currently growing at the annual rate of $10 \%$. According to another study, BMA's demand for water increased from 0.36 million $\mathrm{m}^{3} / \mathrm{day}$ in 1979 to 7.5 million $\mathrm{m}^{3} /$ day in 2000 (Molle et al., 2000). Today, nearly $90 \%$ of Thailand's water use is for irrigation, most of which comes from free surface water. Indeed, Thailand has a long practice of irrigation through river diversion, while the construction of canals for irrigation started at the beginning of the century. According to the Metropolitan Waterworks Authority ${ }^{5}$, the demand for piped water (2.781 million $\mathrm{m}^{3} /$ day) in the BMA exceeded the capacity of waterworks facilities using surface water based resources only ( 2.755 million $\mathrm{m}^{3} /$ day) as soon as 1990 . This resulted in the growing use of groundwater, and in the worsening of ground subsidence problems ${ }^{6}$ : Bangkok is sinking at a rate of about $10 \mathrm{~cm} /$ year, and if this rate continues, most areas of the city will lie below sea-level within the next decade, making flood prevention more complicated and more expensive (Lo and Yeung, 1996).

Increasing demand for water has not only led to an unsustainable reliance on groundwater, but also to the pollution of surface water. According to the 1997 water quality survey (Pollution Control Department), $14 \%$ of surface water resources were suitable for aquatic animals and general human consumption, $49 \%$ were usable for agriculture and general consumption and the remaining $37 \%$ were of poor quality (Tabucanon, 2000). In 1999, the main water problems reported for surface water were low dissolved oxygen, high ammonia nitrogen, high concentrations of fecal coliform bacteria and high turbidity (Adeel et al., 2002). In 2002, the daily effluent in Bangkok was roughly 2.5 million $\mathrm{m}^{3} /$ day, $75 \%$ of which came from households, and $25 \%$ from industries and commercials (UNEP, 2003). The importance of private houses as a major source of pollutants for the lower part of the Chao Phraya River - domestic water is directly discharged into the canals without proper treatment - is confirmed by Simachaya ${ }^{7}$ (2003).

Most farming activities located around Bangkok are highly vulnerable to the quantity and quality of available water. The release of polluted water into irrigation canals causes the farmers to use rain water for irrigation during the rainy season, and to stop irrigating or leave irrigation water to decant

\footnotetext{
http://www.worldbank.or.th/env/2001THAI/ download/ENG/EINTROD.PDF

5 http://www.jbic.go.jp/english/oec/post/2000/pdf/02-19.pdf

6 The problem is being tackled by regulations against groundwater pumping and by increasing MWA's water supply capacity using surface water to substitute for groundwater usage.

7 Conversely, industry was the most significant contributor of pollutants into the lower part of the Thachin River (ibidem).
} 
before using it during the dry season when pollution is more concentrated (because water is scarce). Conversely, water pollution by farming activities may take various forms. Excessive and inappropriate use of pesticides is likely to deteriorate the quality of surface and underground water and may ultimately lead to the poisoning of fish and other aquatic fauna and to the proliferation of aquatic plants. Intensive use of irrigation water may lead to waterlogged soils and water salinity if draining is lacking. High farm water requirements in the dry season could lead to water shortages and conflicts ${ }^{8}$. Fertilizers are likely to cause surface and underground water pollution in four ways: run-off, run-in leaching and atmospheric deposition (Shortle and Abler, 2001). In particular, overutilization of fertilizers may lead to the build-up of phosphates in the soil (ibidem). The discharge of animal (pig, chicken) droppings into the canals may lead to water eutrophication. Discharge of saline water (aquaculture) into the rivers and canals and the seepage of saline water out of the ponds may lead to salinization of nearby agricultural land and water, surface and underground water pollution and crop destruction. The use of stagnant water in ponds may increase the prevalence of water-related diseases (malaria) near the farms. Finally, the use of polluted water by farmers may also threaten the consumers' health. All these problems are exacerbated by the proximity of industries and housing, which contribute further to degrading the quality of the water used by the farmers.

\section{Materials and methods}

- $\quad$ The study area

In the year 2000, a preliminary analysis of the dynamics of peri-urban farming systems was carried out in the vicinity of Bangkok (Gillet and Olliver, 2000). This study was aimed at mapping the distribution of peri-urban activities, at understanding how the spatial distribution of activities evolved over time, and at highlighting the factors of evolution and spatial specialization. One of the main results of the study was the identification of five areas of specialization (fish, vegetables, fruits, rice, and flowers). Four of the five distinctive production areas were kept for our study (Map 1).

$$
<\text { Map } 1 \text { - Location of survey areas > }
$$

The different areas of our survey are subject to various types of problems (Table 1).

$$
<\text { Table } 1 \text { - Summary of potential environmental problems > }
$$

Area 1: between November and December, this area is likely to be flooded since a dike was erected $60 \mathrm{~km}$ North-East from the capital, in order to protect the capital from excess water rushing down from the Chao Phraya river. As a consequence, some villages located in low-land areas can be regularly or exceptionally flooded. Furthermore, this area may be exposed to problems of salinity. Finally, canals in this area are likely to be polluted by waste water released by surrounding houses and shrimp farms.

Area 2: urban pressure is high and increases as one gets closer to Bangkok. This region has attracted factories for 25 years or more; further North, urbanization dates back to 5-10 years. This area is also likely to experience flooding during the rainy season.

Area 3: since many factories are located along the Tha Chin river, the villages located on the river side or along the canals related to the river are often polluted. This area is also plagued by a number of waste disposal sites, which threaten the production of vegetables. In this area, most buildings were erected 5 to 10 years ago.

Area 4: urban growth occurred along the main roads - built 50 years ago to accommodate the larger urban population and business, industrial, and community demand - and near the main towns (Latkrabang, Nongchok). Most factories and housing facilities in this area were built 10-15 years ago. Nevertheless, urbanization remains low in Chachengsao

8 In the lower Chao Phraya Basin, only $35 \%$ of irrigable land receives sufficient water in the dry season. At that time, surface water use for irrigation can lower river flows to a such an extent that they are inadequate for navigation, self-cleansing, and defense against saline intrusion (World Bank, 2001). 
province: $87 \%$ of the total area of the province is used for farming and population density reaches a mere 267 inhabitants $/ \mathrm{km}^{2}$ (Chunnasit et al., 2000). In this area, the quality of rice may be lower at some times of the year due to water deprivation.

Patterns of land use have changed in the BMA over the past 20 years : the south-eastern fringe of the city (Area 1) is mainly evolving away from rice systems towards aquaculture; the northern area (Area 2) combines rice with vegetables and, to a lesser extent, fruit production; in the western area (Area 3), rice is progressively giving way to more intensive fruit production; the north-eastern area (Area 4) is still mainly based on rice although diversification schemes emerge towards aquaculture, and the south-western area is progressively shifting towards the production of ornamental flowers. In the areas where the survey was carried out, although the traditional crop is rice, the diversification process is well under way (Table 2).

$<$ Table 2 - Diversification process in the study areas >

This process of diversification, here understood as "a movement of resources from low value agriculture to high value agriculture" (Joshi et al., 2003, p. 3) or as the progressive replacement of rice by more lucrative crops in the peri-urban area, was identified in other Asian countries such as Vietnam (Jansen et al., 1996; van den Berg et al., 2003), Malaysia or Nepal (Midmore and Jansen, 2003). However, the shift towards the production of higher-value crops may be constrained by land speculation, by the competition between farm and non-farm activities in terms of output and income generation and by the availability of labor (Satterthwaite and Taneja, 2003). The amplitude of the diversification process is related to the existence of successful experiences nearby and to the availability of skilled manpower. It may also be influenced by the existence of migration flows, since newcomers are likely to introduce new farming practices: this was namely the case for the cultivation of vegetables by Chinese migrants. The type of land tenure is also an important determinant of the extent of diversification, since it determines both the farmers' aversion to risk (and thus their investment propensity) and the type of activities undertaken: indeed, high rental fees are good incentives for farmers to move towards more profitable crops, yet farmers are less likely to make large investments on rented land, especially in the peri-urban area. The features of soil and the conditions of access to water may also limit diversification or render it more attractive, as may pollution and other negative externalities caused by neighboring activities. Proximity of the farm to existing markets and infrastructures are other important criteria. The cost of the initial investment required to start the new activity, its irreversibility and the degree of risk of the new activity must also be taken into account (e.g. shrimp farms). Finally, the extent of public intervention (development of infrastructures, government aid, etc.) may further incite or discourage diversification.

- $\quad$ The survey

Two sets of on-farm surveys were carried out for this study, bringing together specialized production systems devoted to a single crop (rice, vegetable, fruit, fish, shrimp) and mixed production systems combining two of the previously mentioned activities. A quantitative survey was undertaken in August-September 2001, in the very same areas identified by Gillet and Olliver (2000) and presented on Map 1 and in Table 2), which represent areas of dynamic specialization of farmers. In each area, the sampling of the villages to be surveyed (7-9 per area) was undertaken according to various factors (distance from Bangkok, farm area, main production patterns reported by the census of the Ministry of Agriculture). During this first survey, a total of 107 farmers were interviewed. A somewhat smaller qualitative survey was carried out in February 2002 on the very same sample of farms. This survey focused on the perception of water quality, and on the effects of chemicals on the farmers' health. A total of 23 interviews were carried out.

\section{MAIN FEATURES OF THE FARMS}




\section{Size and ownership of the farms}

Farms are quite small (3.7 ha on average), which may be explained both by the proximity to the city and by fact that many farmers sold plots of land when land prices where high (between the late 80s and the mid 90s) ${ }^{9}$, thus leading to a reduction in the size of the farms and to massive inflows of cash. The largest farms are those where rice cultivation is undertaken alone, or together with another activity such as shrimp farming. The smallest farms are those where shrimp farming is the main activity. Farms are significantly larger in Chachengsao (7.3 ha on average) and Bangkok (6.2 ha on average) provinces than in Samut Sakhon (1.5 ha on average), which may be explained by differences in urban pressure. More than half of the farmers (64\%) own their land, for which they pay an average land tax of 144 baht/ha/year (US \$3.2/ha/year ${ }^{10}$ ). The remaining $36 \%$ who rent their land, pay an average rent of 6,876 baht/ha/year (US\$ 150/ha/year). Still very rural, Chachengsao province has the lowest average land tax and rental fee. The highest average land tax is in Samut Sakhon and the highest average rental fees are in Nakhon Pathom and Samut Sakhon, two increasingly industrialized areas.

\section{Areas, yields and revenues}

Traditionally cultivated as a single crop, rice is increasingly grown in combination with higher valued crops (fruit trees, fish, shrimp), as the city's boundaries are pushed further out and new roads are built. Farmers grow rice to secure their income, because rice remains the main food staple, and to maintain tradition as well as their land, and finally to control for pests and diseases in rotated vegetable crops (van den Berg et al., 2003). In our sample, the average size of rice-planted areas is $4.8 \mathrm{ha}$, with a minimum of $1.2 \mathrm{ha}$, and a maximum of $13.3 \mathrm{ha}$. The largest areas are those where rice is grown alone or in combination with shrimp. Rice plots in Chachengsao province are significantly larger than those located in the other provinces. The smallest rice-planted areas are for the "rice and fish" mix. Most farmers grow two crops of rice per year and some grow three crops, which explains the high average yield for rice $(10.7 \mathrm{t} / \mathrm{ha} / \mathrm{year})$. The price of rice reported by the farmers ranges between 3 and $4.2 \mathrm{baht} / \mathrm{kg}$ (US\$ 0.066 to $0.093 / \mathrm{kg}$ ), and the average yearly revenue $^{11}$ from rice is 39,577 baht/ha/year (US\$ $882 /$ ha/year).

North of Bangkok, vegetable cultivation has been practiced for years by Chinese migrants along the canals. Vegetables replaced rice because their yields are higher on small surfaces, which combined with their high market price makes them more profitable on urban and peri-urban plots. As the city expands and urban pressure increases, rice is progressively replaced by vegetable farms along the canals. The average vegetable area is 0.8 ha. Farmers generally grow 2-3 different species $^{12}$. The average yield for vegetables is 25 tons/ha/year. The price of vegetables ranges from $2 \mathrm{baht} / \mathrm{kg}$ (US\$ $0.044 / \mathrm{kg}$ ) for lemon grass to $150 \mathrm{baht} / \mathrm{kg}$ (US\$3.34/kg) for water mimosa. The average yearly revenue of vegetable growers is 200,316 baht/ha (US\$ 4,466/ha).

Shrimp production is a recent activity. Most shrimp farms are located on the south-western fringes of Bangkok. Most are on owned land. Some farmers financed their activity by selling some land to urban developers and by borrowing money from the bank, using their land as a guarantee. Other farmers worked in factories and returned to the farm after the financial crisis of 1996, using their savings to start producing shrimp or fish. The average shrimp area is 1.1 ha. The average yield of shrimp is 6.6 tons/ha/year. The price of shrimp varies between 80 baht $/ \mathrm{kg}$ (US\$ 1.78/kg) for and

9 According to Askew (2000, p. 17): “The logic of a landholder selling only part of his/her rice-fields is based on a strategy of maximising the uses of assets for the household, particularly preserving sections for passing on to children and retaining still-productive or otherwise useful land. (...) [this] offered farmers the advantage of paying their debts while preserving sections of their land for continued production".

10 At the time of the survey, the exchange rate was roughly 1 US $\$=44.84$ Thai baht.

11 In this section, revenues are defined as the total amount of sales, i.e. as the production multiplied by market prices (Jansen et al., 1996)

12 Mainly leafy (convolvulus, water mimosa, Chinese kale, Chinese chive and lettuce) and fruit vegetables (tomato, eggplant, chilies or okra). 
550 baht $/ \mathrm{kg}$ (US\$ 12.26/kg), with an average price of 184 baht $/ \mathrm{kg}$ (US\$ 4.1/kg). The large variation in the price of shrimp may be explained by the final market targeted by the farmers (export vs. local market). The average yearly revenue from shrimp is 1,398,842 baht/ha (US\$ 31,196/ha).

Fish ponds started replacing rice when soil salinity, water pollution, the presence of pests, and the reduction of farm land contributed to reducing rice yields. The first farmers obtained their capital from the sale of cattle and land and by borrowing from the bank. After 1980, many fish farmers benefited from the help of local agricultural services. Fish farms generally consist of one or several ponds, sometimes surrounded by fruit trees (generally for self-consumption). Further diversification of this activity includes growing water mimosa and raising small cattle and exotic fish. The average fish area is $2.0 \mathrm{ha}$. The average yield of fish is $10.8 \mathrm{tons} / \mathrm{ha} / \mathrm{year}$. The price of fish varies between $6 \mathrm{baht} / \mathrm{kg}$ (US\$ 0.13/kg) and $150 \mathrm{baht} / \mathrm{kg}$ (US\$3.34/kg), with an average price of $23 \mathrm{baht} / \mathrm{kg}$ (US\$ 0.5/kg). The average yearly revenue from fish is 286,256 baht/ha (US\$ 6,383/ha).

Orchards are traditionally located on the western bank of the Chao Phraya river. Farmers grow 1-3 different types of fruit, including banana, guava, mango, grapefruit, lemon, coconut, areca nut and rose-apple. Although fruit trees may be grown alone, "rice and fruit" and "fish and fruit" combinations are widespread. The average size of fruit tree areas is 0.8 ha. The average yield for fruit production is 5.8 tons/ha/year. The price per fruit varies between 0.1 baht per fruit (areca nut) and 40 baht per fruit (grapefruit). The price per kilo varies between 3.5 baht $/ \mathrm{kg}$ (US\$ 0.78/kg) and $50 \mathrm{baht} / \mathrm{kg}$ (US\$ 1.11/kg). The average yearly revenue from fruit is $110,525 \mathrm{baht} / \mathrm{ha}$ (US\$ 2,465/ha).

Table 3 - Area, yield and revenues for various crops

Shrimp is by far the most rewarding activity, followed by fish, vegetable, fruit and rice. This quite simple result must be qualified by two remarks.

First of all, Table 3 shows a great variation in yields, revenues and prices. Indeed, one of the striking results of this survey is the great heterogeneity in the urban and peri-urban farms surveyed. Some small farmers raise fish in a traditional way for their own consumption or for local markets on which prices are low, others raise fish in large ponds for export markets, comply to international standards and benefit from higher prices. The same opposition is true for the other crops, which makes it quite difficult to aggregate the results.

Second, when taking into account the combinations of activities undertaken by the farmers, the picture becomes more complex. For example, the revenue for farms that raise fish alone is not very rewarding, mainly because most of the farms in this category raise fish in a traditional fashion, either for self-consumption or for barter. It is most likely that such farms receive additional revenues from some family members working in the nearby city (unfortunately, this remains an hypothesis, as the farmers were not questioned about off-farm or non-farm activities). The "rice and fruit" combination represents another rather traditional and widespread production system where a few fruit trees grow spontaneously around rice fields. Again, this combination is only marginally oriented towards the market: only surplus fruit is marketed, thereby providing a small extra revenue. Fruit and vegetables, when grown alone, yield medium range revenues - both activities require a fair amount of labor and input. The income from the "fish and shrimp" combination is also quite high, which may be explained by the fact that the production techniques used for fish in these farms are far more intensive than those developed in the farms where fish is grown alone in a traditional way. Variance analysis shows that yearly revenues from fish, when undertaken together with rice, are significantly higher, at $95 \%$ level, than when fish is produced alone or in combination with any other activity. For all other crops and combinations, differences between commodities are non significant at this level.

\section{Use of inputs}

The most widely used inputs are fuel, seeds, organic materials, calcium enrichment, chemical fertilizers, pesticides, herbicides and hired labor. Many farmers also use, on a more or less regular basis, a series of services including transportation and the rental of machines. Since land taxes and 
rental fees cannot be allocated to a particular commodity, they will be introduced later in our analysis. For each type of input, we indicate the amounts used on the farm and the cost incurred by the farmers for the purchase of these inputs (unit cost multiplied by total amount).

Organic material. Vegetable farms are the biggest users of organic material (animal waste, compost, rice straw, peanut husk). The average amount of organic material used by the farmers of our sample is $9.7 \mathrm{t} /$ ha/year: rice plots use a mere $0.5 \mathrm{t} / \mathrm{ha} /$ year, while vegetable plots consume 5.2 $\mathrm{t} / \mathrm{ha} /$ year and fish ponds consume $18.8 \mathrm{t} / \mathrm{ha} /$ year (the differences between the activities are significant at $95 \%$ level).

Chemical fertilizers. Use of chemical fertilizers varies greatly among farmers. In terms of nutrients, average applications of NPK are detailed in Table 4.

Table 4 - Average quantities of chemical fertilizers used in rice, vegetable and fruit production

In terms of costs (Table 5), fertilizers represent $30 \%$ (rice, vegetables) to $40 \%$ (fruit) of total costs. They are used by all rice farmers and by $80 \%$ of vegetable and fruit farmers. Processed food represents half of the total costs for shrimp production and $60 \%$ for fish production. It is used by $88 \%$ of the shrimp farmers. Only half of the fish farmers use processed food, and $46 \%$ use organic waste together with (or instead of) processed food. Pesticides are used by $93 \%$ of the rice farms, $71 \%$ of the vegetable farms, $58 \%$ of the fruit farms and half of the shrimp farms.

Hired labor. We define labor costs as the wages paid to non-family workers. $84 \%$ of the farmers depend mainly on family workers to run their farm, yet hire seasonal workers for labor-intensive tasks such as thinning or harvesting. The remaining $16 \%$ employ an average of 3 permanent salaried workers on their farm. Very few fish farmers employ hired labor. The cost of hiring labor represents roughly $15 \%$ of the total costs for rice, vegetable and fruit, but only roughly $2 \%$ of the total costs for shrimp and fish farms. Hired workers are used by $13 \%$ (rice and fruit) and $19 \%$ (vegetables) of the farms.

Machine rental and fuel costs. These costs represent one quarter of the total costs for rice farms, where specialized equipment is used in a very seasonal pattern; they represent $10 \%$ for fruit and vegetables, and are minimal for fish and shrimp farmers (who invest massively in permanent equipment).

\section{Table 5 - Average costs per activity}

Aquaculture farms bear the highest costs, while rice farms bear the lowest. Growing fruit trees involves fairly low costs since the trees are often grown along the rice fields or ponds, and do not require much care or many inputs.

Variance analysis at the $95 \%$ level shows a series of interesting features:

- the costs per hectare of the "rice and fish" combination are significantly higher than the sum of each of the two specialized activities: 510,000 baht/ha/year (US\$ 11,371/ha/year) for "rice and fish”; 20,000 baht/ha/year for rice (US\$ 446/ha/year); 134,000 baht/ha/year for fish (US\$ 2,988/ha/year). In such farms, input costs for the fish activity are significantly higher than those in all other fish farms of our sample (these farms spend more on food, lime and juveniles).

- the total input costs of the shrimp farms are significantly higher than those of the farms combining shrimp with other crops (higher costs for food, pesticide, calcium and transportation). This might hint at the fact that such farms are also specialized in terms of the variety of shrimp they raise, thus suggesting some kind of segmentation of shrimp farming with, on the one side, specialized, modern farms raising fragile, high-value shrimp for export markets and, on the other, more traditional farms raising common shrimp for the local market. This may explain why the costs of the "fish and shrimp" combination are lower than the sum of the costs for the two specialized activities: 459,000 baht/ha/year (US\$ 10,234/ha/year) for the "shrimp and fish" combination; against 1,383,000 baht/ha/year (US\$ 30,840/ha/year) for shrimp and 134,000 baht/ha/year (US\$ 2,988/ha/year) for fish. Economies of scale might also be attained when combining the "traditional shrimp" with the fish activity, two closely-related activities in terms of inputs; 
- the costs for the "rice and shrimp" combination are also lower than the sum of the costs of the two specialized activities: 443,000 baht/ha/year (US\$ 9,879/ha/year) for the "rice and shrimp" combination; 20,000 baht/ha/year (US\$ 446/ha/year) for rice and 1,383,000 baht/ha/year (US\$ 30,840 ha/year) for shrimp.

\section{Income and net income per family worker}

The income was calculated as the difference between (a) the revenue per hectare per year, (b) the input costs per hectare per year and (c) the non-crop specific input costs per hectare per year, such as land rents and tax fees (these elements are proportional to the surface of land cultivated by the farmer). Proportional depreciation also covers the price of the fruit trees bought by the farmers (fruit trees are an investment for the farmers, since it takes a few years for the young trees to reach maturity). Non-proportional depreciation was calculated as the annual sum allocated to the replacement of the farms' equipment (tractors, pumps, ponds) e.g. the value of the equipment divided by its expected life time.

Table 6 - Income calculation for the main crops

Table 6 shows that shrimp is the crop with both the highest income (736,800 baht/ha/year or US\$ $16,430 /$ ha/year) and the highest costs. Indeed, annual costs amount to 665,000 baht/ha/year (US\$ 14,830/ha/year), while non-proportional depreciation reaches 15,200 baht/ha/year (US\$ 339/ha/year), mainly because of the considerable investments required (pumps, ponds, pipes, paddles, etc.). This means that shrimp is a rewarding activity with very high barriers to entry. In the other activities, low investments may be explained by low scales of production. Although rice farms have the lowest income, they require some investments (tractors, pumps) because of their larger size. Finally, the net income per family worker (NIFW) was calculated following the methodology developed by Dufumier (1996):

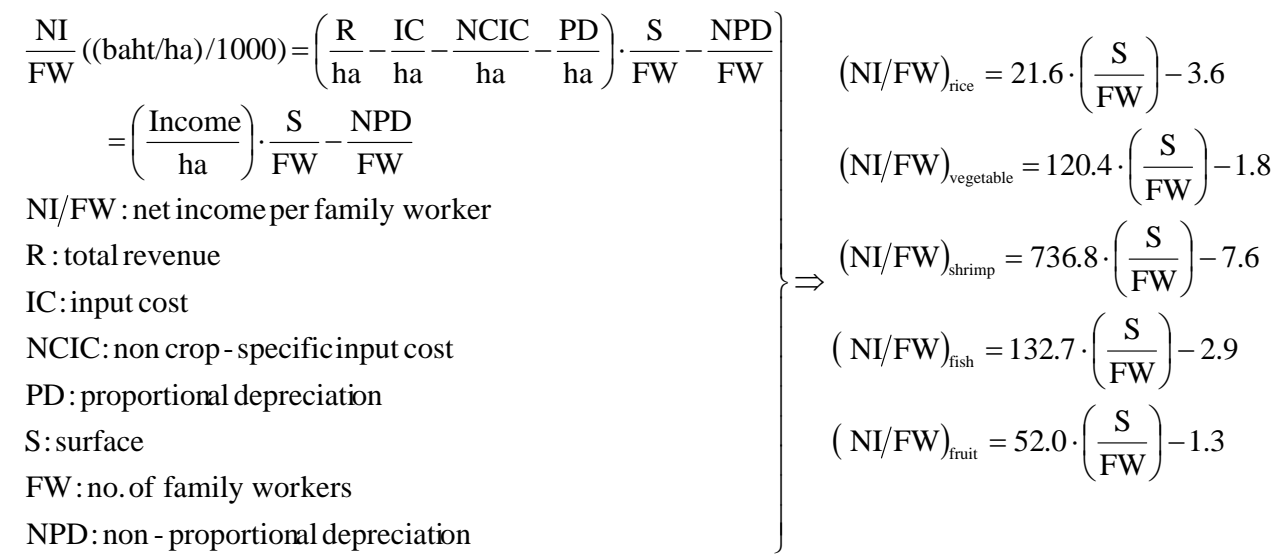

When applying the above formulas to the average surface for each activity, the net income per family worker is : 32,023 baht/ha/year (US\$ 714/ha/year) for 4.8 ha of rice; 27,330 baht/ha/year (US\$ $610 /$ ha/year) for 0.8 ha of vegetables; 397,647 baht/ha/year (US\$ 8,868/ha/year) for 1.1 ha of shrimp, 88,621 baht/ha/year (US\$ 1,976/ha/year) for 2 ha of fish and 13,059 baht/ha/year (US\$ 291/ha/year) for 0.8 ha fruit. The relatively poor performance of fruit and vegetables in terms of net income per family worker, compared to their performance in terms of income is explained by their very low surface to family worker ratio ( 0.3 for fruit and 0.2 for vegetables). These figures may be compared with the minimum wage of 2,284 baht/month (US\$ 51/month or approximately US\$ 610/year) in 2001 (statistics of the Labour Force Survey can be consulted on the National Statistical Office of Thailand website, at http://web.nso.go.th/eng/stat/lfs_e/lfse-tab7.xls). 


\section{$<$ Table 7 - Summary of main economic results $>$}

Finally, the main results of the economic analysis (Table 7) show that shrimp farming remains by far the most rewarding activity, with an income per hectare of US\$ 16,400/ha/year. Fish farming, the second most lucrative activity in our sample, barely offers US\$3,000/ha/year (5.6 times less than shrimp farming). However, it is worth noting that the input costs incurred by shrimp farmers are also quite high (14,800/ha/year). The ratio of input costs to value added (which indicates the intensity of input use) reveals an efficient use of inputs, especially in vegetable farms. However, vegetable growing is the most labor-consuming activity with 682 man-days/ha/year, while rice requires a lot less labor (42 man-days/ha/year). As a result, horticulture has the lowest income/labor rate of all activities surveyed ( $4 \$$ man-day). It is worth noting that these figures are slightly above those found for the Mekong Delta in the mid-90s (Le Coq and Trebuil, 2005).

\section{ENVIRONMENTAL ISSUES}

\section{Water pollution and its consequences for the farmers}

Water pollution is an important problem for most farmers: $71 \%$ of the farmers of our sample mention experiencing problems caused by polluted water at least once a year. Polluted water here designates water that is improper for agricultural use (mainly because of high concentrations of harmful substances such as chemicals, waste, salt, etc.).

According to the farmers, the main sources of pollution are the proximity to: residential areas (mentioned by 11 out of 17 farmers interviewed); factories located upstream (8/17); and shrimp (7/17), rice (5/17) and fish farms (4/17). Farmers assess the quality of water by checking its color (and for the presence of dead fish) and by smelling it. Some shrimp farmers also use equipment to measure the acidity of canal water. Finally, some farmers are informed by the head of their village when it is risky to use the water (however, no information was provided about where this information initially came from). The main effect of water pollution, which may occur one to several times per year, is the potential destruction of part of or all of the crop. It is important to mention here that water pollution is an issue mainly for fish and shrimp farms. Rice seems to be less fragile a crop. Moreover, since rice farms yield a lower income, they are located further away from the city in less densely populated areas, where pollution is likely to be less significant a problem (rice farmers are more troubled by saline intrusions and water shortages than by water pollution).

The solutions adopted are far from satisfactory both in terms of health and in terms of the environment: $43 \%$ of the farmers stop using water when it is polluted, $31 \%$ continue using polluted water, $8 \%$ clean it with appropriate chemicals, $8 \%$ obtain their water from another source and $8 \%$ let it decant. In our second survey, most farmers declared using rain water for cooking and drinking, tap water for bathing and canal water for all their farming activities (crops, animals, ponds). All but three farmers consider that the water they draw from the canal is sometimes so polluted that it may be improper to use on the farm. Farmers also face water shortages during the hot season (April-May) that are likely to aggravate their problems: indeed, when less water is available, pollution is more concentrated. Among the farmers who consider canal water as sometimes polluted, over $70 \%$ (12/17) find the water they use "not so clean". None of the farmers consider the water as "very clean" or "very dirty". All the farmers think the water is more polluted than 10 years ago, saying it was then possible to drink the canal water or swim in it, and that the species of fish were more numerous. Since canal water is free (and its access unlimited), none of the farmers interviewed was able to assess the total amount of water used on the farm other than by saying how many hours they pump the water, or the level of water in the ponds ${ }^{13}$.

13 According to Molle et al. (2000), the average consumption of water reached 10,000 $\mathrm{m}^{3} /$ ha for the 1977 1999 period, "with a significant spatial variability and a slight temporal decline". Tixier et al. (2005) evaluated water consumption by various vegetable farms in tropical areas at $4,000-8,000 \mathrm{~m}^{3} / \mathrm{ha} / \mathrm{year}$ for tomato; $1,500-3,000 \mathrm{~m}^{3} /$ ha/year for non-leafy Chinese cabbage and 4,500-9,000 m³/ha/year for cucumber. 
Except for the rice farmers (who claim not to have water-related problems), none of the farmers use water directly from the canal all year round. In aquaculture, chemicals and decantation ponds are used throughout the year. Vegetable growers use decantation ponds only when canal water cannot be used. As a result, the cost of tackling the problem of water pollution varies greatly from one activity to the other (Table 8).

\section{$<$ Table 8 - Cost of water pollution for the farmers $>$}

Vegetable and shrimp farmers use decantation ponds and pumps, which we consider as investment. Vegetable farmers of our sample paid on average $300 \mathrm{baht} / \mathrm{ha}$ (US\$ 18/ha) for decantation ponds and 500 baht/ha for pumps. Shrimp farmers paid 4,500 baht/ha (US\$ 100/ha) for ponds alone. As a result, the amount of non-proportional depreciation per family worker increases from 1,800 baht to 2,000 baht/ha/year for vegetables, and from 7,600 to 8,500 baht/ha/year for shrimp. Shrimp losses caused by water pollution were quite high; they reached 30,000 baht/ha/year (US\$ 670/ha/year). Finally, survey results show that the fish farmers of our sample either do nothing at all or use chemicals when the water is polluted. Table 8 shows the farmers' own assessment of both the losses of product caused by the use of polluted water in the fish ponds $(8,400 \mathrm{baht} / \mathrm{ha} / \mathrm{year}$ or US\$ $187 / \mathrm{ha} / \mathrm{year})$, and the cost of the chemicals used for decontaminating the water $(1,100 \mathrm{baht} / \mathrm{ha} / \mathrm{year}$ or US\$ $25 /$ ha/year). Since the farmers do not use ponds or special equipment to clean the water, the non-proportional depreciation remains unchanged (only the income per hectare changes).

As a consequence, the net income per family worker per hectare is altered as shown in Table 9:

$<$ Table 9 - Changes in the net income per family worker when water pollution is taken into account $>$

Vegetable farmers incur both higher investment and higher overall costs: (a) non-proportional depreciation per family worker increases by 160 baht/ha/year; (b) input costs increases by 1,000 baht/ha/year. Shrimp farmers bear higher investment costs and higher overall costs: (a) nonproportional depreciation per family worker increases by 900 baht/ha/year; (b) input costs increase by 38,000 baht/ha/year. For fish farmers, only the net income per hectare is reduced, because of losses and higher input costs (9,500 baht/ha/year).

Although none of the farmers interviewed pays for the water they use, most of them (14/17) are ready to pay for access to clean water. Those who refuse to pay (3/17) do so because their income is too low, because water pollution is not a major issue for them or because they think that those who pollute should pay, not them (Table 10).

\section{$<$ Table 10 - Main results of the water survey >}

Finally, the farmers were asked how much they were willing to pay for access to unpolluted water ${ }^{14}$. The average amount that the interviewed farmers were willing to pay for unpolluted water is 1,196 baht/ha/year (US\$ 27/ha/year). It becomes 1,025 baht/ha/year (US\$ 23/ha/year) when including the farmers who are not willing to pay for unpolluted water. The average willingness to pay is higher for vegetable (3,200 baht/ha/year or US\$ 71/ha/year) and shrimp (890 baht/ha/year or US\$ 20/ha/year) farmers than for fish farmers (220 baht/ha/year or US\$ 5/ha/year).

Paying more for clean water seemed an odd suggestion for the farmers who struggle to cover their expenses and who have already solved their water problems thanks to practical and cheap "solutions" (no watering, use of decantation ponds). Moreover, many of the farmers interviewed do

Consumptive use of water by shrimp farms in the Chao Phraya area is estimated at approximately 7,300$9050 \mathrm{~m}^{3} /$ ha/crop (Braaten and Flaherty, 2000).

14 The initial bid made to the farmers was to pay 1,000 baht per year for access to clean water. If this amount was accepted, a higher amount was proposed, and this procedure was continued until the farmers refused. If the initial amount was rejected, a lower amount was proposed until the farmers accepted. All farmers except two understood the game and were able to accept or to reject the price proposed. 
not believe in the likelihood of the water ever being clean enough (they would accept to pay if the water was "really clean"). This means that the farmers would probably keep cleaning the water even after the treatment plant was set up, until they fully trusted its efficiency. This highlights the need not only for improved water treatment facilities, but also for an independent agency responsible for monitoring the quality of canal water and for improved communication about the treatment facility and its efficiency. It is worth mentioning that the "polluter pays" principle would probably be quite difficult to implement in such an area where the number of water users is high and the access to canal water very easy - making it virtually impossible to identify polluters. Finally, the survey highlights the importance of taking into account the grouping of farmers when dealing with such a collective good as canal water. Many farmers declare that their willingness to pay is related to that of the other farmers of their group ("If the group agrees, I agree too"). It would thus be quite interesting to carry out interviews and simulations at the group level and not to focus only on the negotiation process that takes place among the individual farmers. Meetings involving the different stakeholders (farmers, house estate residents, public authorities, plant managers, etc.) should also be organized.

\section{The use of chemicals and its consequences for the farmers}

The farmers of our sample use, on average, $18 \mathrm{~kg} / \mathrm{ha} /$ year of herbicides, $33 \mathrm{~kg} / \mathrm{ha} /$ year of pesticides (fungicides and insecticides) and $590 \mathrm{~kg} / \mathrm{ha} /$ year of nutrients (Table 11).

< Table 11 - Amount of nutrients, herbicides and pesticides >

Vegetable farmers are the biggest consumers of organic material ${ }^{15}$ (5.2 tons/ha/year on average). They also use larger amounts of nutrients through chemical fertilizing (728 kg/ha/year) and more pesticides (18 kg/ha/year) than the two other crops presented here. In comparison, vegetable farmers in South Vietnam use more manure (7.6 tons/ha/year) and less chemical fertilizers (534 $\mathrm{kg} / \mathrm{ha} / \mathrm{year}$ ), while cereal farmers use both less manure (2 tons/ha/year) and less chemical fertilizers (190 kg/ha/year) (Ali, 2002). This may be explained by the higher cost of chemical fertilizers compared to that of organic material. South Vietnamese vegetable farmers also use a little less pesticides (14 kg/ha/year) and much less herbicides (0.6 kg/ha/year). Cereal farmers use roughly the same amount of pesticides (6.5 kg/ha/year) and half as much herbicides (1 kg/ha/year). Other studies focus on the high amount of organic and chemical nutrients used by vegetable farmers in South-East Asia (Jansen et al., 1996; Midmore et al. 1996; Poudel et al. 1998).

A strong relationship is evident between the input of nutrients through chemical fertilizing and rice yields expressed in $\mathrm{kg} / \mathrm{ha} / \mathrm{year}$ (Figure 1). Conversely, the relationship between the amount of herbicide used and rice yields per hectare and per year seems quite weak. The same analysis for fruit farms shows a non-significant relationship between the use of fertilizers and yields (Figure 2).

$<$ Figure 1 - Use of fertilizers and yield: rice >

$<$ Figure 2 - Use of fertilizers and yield: fruit $>$

Pesticides are quite widely used by the vegetable $(17.6 \mathrm{~kg} / \mathrm{ha} / \mathrm{year})$, rice $(5.6 \mathrm{~kg} / \mathrm{ha} /$ year $)$ and fruit $(11,4 \mathrm{~kg} / \mathrm{ha} /$ year) farmers of our sample. However, a strong relationship seems to exist between the amount of pesticides used and the yield mainly for vegetables (Figure 3), and to a lesser extend for rice. The poor relationship between the amount of pesticides used and fruit yields seems to hint at an inefficient use of pesticides.

< Figure 3 - Use of pesticides and yield: vegetables >

Finally, it is worth noting the absence of a direct relationship between the use of herbicides and yields for rice, vegetables and fruit. This may be explained primarily by the fact that the farmers of our sample use wide range herbicides (e.g. glyphosate or paraquat dichloride) that might not be very adapted to the weed likely to invade their crops. Moreover, farmers tend to use the herbicides improperly (they have problems identifying the type of herbicide they need). Finally, manual weed

15 Organic material includes animal waste, compost, rice straw, peanut husk. 
control is still quite widespread, especially among vegetable (33\%) and fruit farmers (36\%). These results highlight the need for more detailed information on the types of chemicals used by the farmers. It would also be interesting to relate the use of pesticides to yield benefits.

Table 12 summarizes the results obtained for various scenarios. The land area considered is the average for each crop, as described in Table 3. Two scenarios are compared:

- the baseline scenario (scenario I) corresponds to the first calculation of the net income per family worker;

- scenario II takes into account the cost of water pollution for shrimp, vegetable and fish farms

On the average vegetable farm, the income per family worker falls by 425 baht/ha/year (US\$ 9.5/ha/year). On the average fish farm, the income per family worker falls by 6,500 baht/ha /year (US\$ 145/ha/year).

$<$ Table 12 - Summary of results $>$

\section{SUMMARY AND DISCUSSION}

Bangkok offers an interesting example of how agricultural and urban activities may coexist, and of the forces at work on the fringes of this huge and continuously growing city. Competition over alternative land uses results in soaring land prices and complex patterns of space organization, while households arbitrate between allocating their labor to industrial or agricultural activities. These observations have led us to study the general profile and profitability of peri-urban farm systems and to assess some of the environmental problems encountered by the farmers.

\section{Summary of results}

Our main results indicate that the farms surveyed are quite small, although there are differences according to the activity undertaken (vegetable farms are the smallest, rice farms are the largest). Almost all farms have free access to water and rely heavily on family labor. In monetary terms, the most rewarding activity is specialized shrimp farming; the least rewarding is specialized rice farming. Although all crops are profitable, some activities such as rice farming do not generate high revenues, which suggests that they may be financed by the household's other sources of income and serve as a means to keep the land for speculative motives. Indeed, being located where the city expands, peri-urban plots of land are likely to be converted into more remunerative land uses (e.g. house and industrial estates) in a short future. The highest input costs concern fertilizers (30-40\% of total costs) and pesticides (3-26\% of total costs). Organic material is not very widely used by the farmers, except by vegetable and fish farmers, who use respectively a little over 5 tons/ha/year and 18 tons/ha/year. These figures are very close to those reported by previous analyses (Ali, 2002; Jansen et al., 1996). Hired labor represents between 2\% (fish and shrimp farms) and $15 \%$ (other activities) of total input costs. A comparison of the different activities in terms of costs shows that shrimp farms bear the highest costs, while rice farms bear the lowest. Shrimp farms have the highest income, net income per family worker ${ }^{16}$, investment and input costs. This makes shrimp farming a remunerative activity with high barriers to entry. Rice farms have both the lowest income and the lowest net income per family worker, but make an efficient use of labor. Vegetable and fruit farms appear to be burdened by high labor requirements. When taking into account the costs of cleaning the water, shrimp farming still remains by far the most rewarding activity. However, it is worth mentioning that our study does not include a thorough analysis of all of the costs induced by water pollution, including the cost of treating the water with chemicals, the cost of decanting the water, the opportunity cost of not using the water and the product losses caused by the lack of water and/or the use of polluted water. The main reason for this is that access to water is mostly free, which makes it very difficult for farmers to evaluate how much water they use for a given period. A more detailed analysis of water consumption and the related costs is thus crucial to obtain a clearer picture of the real cost of water pollution for each activity.

16 These results are consistent with those of other studies (Flaherty et al., 1999). 


\section{Implications for policy and research}

The previous results stress the need to improve the environmental sustainability of peri-urban agriculture by improving the overall environment in which the farms operate and by limiting the negative impacts of peri-urban agriculture on its surroundings. More precisely, the results stress the need to monitoring and upgrade the quality of canal water, to regulate land uses along the canals, and to limit the releases of waste water into the canals ${ }^{17}$. However, the management of free canal water is a tricky issue: canal water can be considered as a common-pool resource in the sense that it is rivaled but non-excludable. Problems arise when the users located upstream use too much water and release their waste into the canal, leaving the users located downstream with limited quantities of polluted water. In the presence of common-pool resources, there is clearly a collective-action problem since the actors must prevent the excessive use of the shared resource (Ostrom and Gardner, 1993). In the case of canal water, the major difficulty stems from the difficulty to identify clearly what the land uses are along the canal, who uses canal water, how much water they use; and to estimate the volume of waste water released into the canal by each type of user. Problems are easier to overcome where social ties are strong (Marwell, Oliver and Prahl, 1988), especially when cooperation between the actors is involved, which is the case of common-pool resources. Cooperation should thus be fostered by identifying and bringing together the main users of canal water (farmers, communities, industries, land owners, etc.) to discuss the problems related to water use and pollution ${ }^{18}$. This task could be carried out by city planners. Unfortunately, peri-urban agriculture still remains fairly unrecognized and, as a consequence, is not much integrated into urban planning and zoning (Drescher, 2001). This situation calls for further informing urban planers under what conditions may peri-urban agriculture improve the quality of life in the city (Doucouré and Fleury, 2004). Namely, developing and promoting a more reasonable application of chemicals and the adoption of environmentally friendly farming techniques (nets, integrated pest management, grafting techniques) are other paths that should be explored by public authorities to help peri-urban agriculture become more sustainable and therefore more acceptable.

In terms of research, several questions remain unanswered. First, although the five activities analyzed are economically profitable in the short run, the results must be mitigated by the difficulty of thoroughly assessing their long term environmental impact. Concerning water management alone, the dense network of farming, industrial and housing activities in the peri-urban area, combined with a relatively free management of water resources makes it very difficult to assess the amount of water used and of waste water released by the main actors of the peri-urban interface. Second, the great diversity of actors and - among similar actors - the great variety of behaviors, makes it difficult to clearly identify homogenous groups of actors showing close characteristics and following identical technical paths. It thus seems important to extend this study to a larger number of observations, so as to enhance the reliability of the statistical results. Moreover, some of the results (e.g. the traditional fish activity) seem to hint at the need for a more thorough investigation of the close interconnection between the households' farm and non-farm activities. Indeed, only by taking into account the various sources of income of the household may we understand why the relatively less profitable activities persist in the peri-urban environment. This need for a more comprehensive assessment of the households' characteristics, and of how they operate, could be satisfied by the completion of a series of in-depth case studies. Finally, the very dynamic nature of the peri-urban environment underlines the need for a historical analysis, which would focus on the households' responses to changing incentives and constraints.

\section{REFERENCES}

Ali, M. (Editor), 2000. Dynamics of vegetable production, distribution and consumption in Asia, AVRDC Publication $n^{\circ}$ 00-498, AVRDC, Taiwan.

17 Moreover, technical improvements could be made (construction of interceptor sewers and treatment plants) to prevent wastewater from being directly discharged into the canals.

18 The actors are often unaware of the negative effects of their actions, especially when they are small. 
Adeel, Z., M. Tabucanon, Y. In-na, M. Thanomphan, G. Wattayakorn, K. Tsukamoto and S. Vongvisessomjai, 2002. Capacity development needs in the Chao Phraya River basin and the Gulf of Thailand, Managing shared waters Conference, 23-28 June 2002, Hamilton, Canada.

Argenti, O., 2000. Food for the cities: food supply and distribution policies to reduce urban food insecurity. Food into cities Collection, DT/43-00 ${ }^{\mathrm{E}}$. FAO, Rome.

Armar-Klemesu, M., 2000. Urban agriculture and food security, nutrition and health. In Bakker, N., Dubelling, M., Gündel, S., Sabel-Kaschella, U., de Zeeuw, H. (Editors) Growing cities growing food. Urban agriculture on the policy agenda. Deutsche Stiftung für Entwicklung (DSE), Feldafing.

Askew, M., 2000. The cultural factor in rural-urban fringe transformation: land livelihood and inheritance in western Nonthaburi. Proceedings of the International Conference "The Chao Phraya Delta : Historical Development, Dynamics and challenges of Thailand's Rice Bowl”, 12-15 December 2000, Kasetsart University: Bangkok, Thailand.

van den Berg, L.M., M.S. van Wijk, Pham Van Hoi, 2003. The transformation of agriculture and rural life downstream of Hanoi, Environment and Urbanization, 15(1): 35-52.

Birley, M.H., Lock, K., 1999. The health impacts of periurban natural resource development. Liverpool School of Tropical Medicine, Liverpool.

Braaten, R. and M. Flaherty, 2000. Hydrology of inland brackishwater shrimp ponds in Chachoengsao, Thailand. Aquacultural Engineering 23(4):295-313.

Chunnasit, B., Pagès, J., Duangngam, O., 2000. "Incidence of Bangkok city development on periurban agricultural patterns and cropping systems evolution”. Proceedings of the International Conference The Chao Phraya Delta : historical development, dynamics and challenges of Thailand's rice bowl, 12-15 December 2000, Kasetsart University: Bangkok.

Dixon, C., 1999. The Thai economy: uneven development and internationalization. Routledge, London.

Doucouré, D. and A. Fleury, 2004. La place de l'agriculture urbaine dans les dispositifs institutionnels et la planification. In O. Smith, P. Moustier, L. Mougeot and A.Fall (Editors), Développement durable de l'agriculture urbaine en Afrique francophone: enjeux, concepts et méthodes. CIRAD/CRDI: Montpellier, Ottawa, 173 p.

Drescher, A., 2001. The integration of urban agriculture into urban planning - An analysis of the current status and constraints.

Dufumier, M., 1996. Les projets de développement agricole - Manuel d’expertise. Karthala, Paris.

Falkus, M., 1993. Bangkok: From primate city to primate megalopolis. In megalopolis : the giant city in History, T. Barker and A. Sutcliffe (Editors), pp. 143-165, Macmillan Press, London.

Flaherty, M., P. Vandergeest and P. Miller, 1999. Rice Paddy or Shrimp Pond: Tough Decisions in Rural Thailand. World Development, 27(12):2045-2060.

Gillet, V., Ollivier, I., 2000. Les agricultures périurbaines de Bangkok et leur dynamique. Final Dissertation. CIRAD-CNEARC-ENITA, Montpellier (France).

Ishii, Y., 1978. Thailand, a rice-growing society. The University Press of Hawaii, Honolulu.

Jansen, H.G.P., D.J. Midmore, P.T. Binh, S. Valasayya and L.C. Tru, 1996. Profitability and sustainability of peri-urban vegetable production systems in Vietnam. Netherlands Journal of Agricultural Science, 44:125-143.

Joshi, P.K., Gulati, A., Birthal, P.S., Twari, L., 2003. Agriculture diversification in South Asia: patterns, determinants, and policy implications, MSDD Paper N 57, IFPRI, Washington.

Le Coq, J.F and G. Trebuil, 2005. Impact of Economic Liberalization on Rice Intensification, Agricultural Diversification, and Rural Livelihoods in the Mekong Delta, Vietnam. Tonan Ajia Kenkyu (Southeast Asian Studies), 42(4):519-547. 
Lo, F.-C. and Y.-M. Yeung, 1996. Emerging world cities in Pacific Asia. United Nations University Press, Tokyo.

Marwell, G., P.E. Oliver and R. Prahl, 1988. Social Networks and Collective Action: A Theory of the Critical Mass. III, The American Journal of Sociology, 94(3):502-534.

Midmore, D.J. and H.G.P. Jansen, 2003. Supplying vegetables to Asian cities: is there a case for peri-urban production?, Food Policy, 28(1):13-27.

Molle, F. C. Chompadit and J. Keawkulaya, 2000. "Dry-season water allocation in the Chao Phraya basin: what is at stake and how to gain in efficiency and equity”, Proceedings of the International Conference The Chao Phraya Delta : historical development, dynamics and challenges of Thailand's rice bowl, 12-15 December 2000, Kasetsart University: Bangkok.

Mounier, A., Kaewthep, K., Charoenloet, V., 1995. Formes et phases de l'industrialisation en Thailande dans une perspective historique. Economies et Sociétés, 24(6):81-126.

Moustier, P., Mbaye A., 1999. Introduction générale. in Moustier, P., Mbaye, A., de Bon, H., Guérin, H., Pagès, J. (Editors). Agriculture périurbaine en Afrique subsaharienne. International Seminar, 20-24 April 1998. CIRAD-CORAF, Montpellier (France), 278 p.

NSO. Report of the household socio-economic survey. Various issues, Bangkok.

Nugent, R., 2000. The impact of urban agriculture on the household and local economies. In Bakker, N., Dubelling, M., Gündel, S., Sabel-Kaschella, U., de Zeeuw, H. (Editors). Growing cities growing food. Urban agriculture on the policy agenda. Deutsche Stiftung für Entwicklung (DSE), Feldafing.

Ostrom, E. and R. Gardner, 1993. Coping with Asymmetries in the Commons: Self-Governing Irrigation Systems Can Work, The Journal of Economic Perspectives, 7(4):93-112.

Pignon, M., 1997. Le delta du Chao Phraya en Thaïlande : diagnostic de la qualité de l'eau - Impact sur les activités agricoles. Final Dissertation. Ecole Supérieure d'Agriculture d'Angers.

Satterthwaite, D. and B. Taneja, 2003. Agriculture and urban development, prepared for the workshop "Integrating rural development and small urban centres: an evolving framework for effective regional and local economic development”, 18-19 March 2003, World Bank/IFC, Washington DC, 29 p.

Sharpley, A., R. McDowell, P. Kleinman, 2001. Phosphorus loss from land to water: integrating agricultural and environmental management, Plant and Soil, 237(2): 287-307.

Simachaya, W., 2003. “A decade of water quality monitoring in Thailand's four major rivers: the results and the implications for management", $6^{\text {th }}$ International Conference on the Environmental Management of Enclosed Coastal Seas, 18-21 November 2003, Bangkok.

Shortle, J.S. and D. Abler (Editors), 2001. Environmental policies for agricultural pollution control, CABI, Wallingford, $240 \mathrm{p}$.

Smit, J., Nasr J., 1996. Urban agriculture, food, jobs and sustainable cities. UNDP, New York, 302 p.

Suehiro, A., 1983. Development and structure of textile industry: 1946-1980. Institute of Developing Economies, Tokyo.

Tabucanon, M.S., 2000. Perspectives of financing of environmentally sound technologies in Thailand, Expert group meeting on the Promotion of new forms of financing for transfer, development and application of environmentally sound technologies, New Delhi 15-17 November, 2000.

Tixier P., H. de Bon and R. Holmer, 2005. Urban horticulture. In van Veehuisen (ed.), Cities farming for the future. RUAF Urban Agriculture Programme, ETC Foundation, Leusden, (in press). 
World Bank, 2001. Thailand Environment Monitor 2000. The World Bank, Washington (USA), p. 26.

United Nations Environment Program, 2003. Bangkok State of the Environment Report. UNEP, Pathumathani.

\section{ACKNOWLEDGEMENTS}

This work is the result of a collaborative project between FAO, CIRAD and Kasetsart University (Bangkok, Thailand). The author would like to thank Kasetsart University for its support. Namely, none of this work could have been carried out without the help of Dr. Sornprach Thanisawanyangkura, vice president for Planning and International Affairs at KU. Similarly, the help of Ms. Onouma Duangngam was crucial for the conduct and the supervision of the survey. The study benefited from the valuable help of Paule Moustier, Jacques Pagès from CIRAD, and Félix Moukoko-Nkombé from FAO. Finally, we would also like to thank Hubert de Bon and JeanFrançois Le Coq from CIRAD for their useful comments.

\section{Tables, Graphs and Maps}

Table 1 - Summary of potential problems caused by the farms' environment

\begin{tabular}{llll}
\cline { 2 - 3 } & $\begin{array}{l}\text { Level of } \\
\text { urban pressure }\end{array}$ & Source of pollution & Type of problems \\
\hline Area 1 & medium & houses, shrimp farms & flooding, salinity, water pollution \\
Area 2 & high & factories & flooding, water pollution \\
Area 3 & medium & factories, waste disposal sites & water pollution \\
Area 4 & low & factories, houses & water shortages, water pollution (dry season) \\
\hline
\end{tabular}

Table 2 - Diversification process in the study areas

\begin{tabular}{lcccc} 
& Area 1 & Area 2 & Area 3 & Area 4 \\
\hline Main traditional crop & rice & rice & rice & rice \\
& $\downarrow$ & $\downarrow$ & $\downarrow$ & $\downarrow$ \\
Main present crop & shrimp & fruit \& vegetable & fruit & fish \& shrimp \\
\hline \multicolumn{2}{l}{ Source: derived from Gillet \& Ollivier (2000). }
\end{tabular}


Table 3 - Area, yield and revenues for various crops

\begin{tabular}{|c|c|c|c|c|}
\hline & $\mathrm{N}^{\mathrm{a}}$ & Mean & Min. & Max. \\
\hline Rice & 30 & & & \\
\hline Area (ha) & & 4.8 & 1.2 & 13.3 \\
\hline Yield (t/ha/year) & & 10.7 & 2.4 & 18.0 \\
\hline Total revenue (,000 bath/ha/year) & & 39.6 & 5.5 & 75.2 \\
\hline Labor (man days/ha) & & 42 & 19 & 82 \\
\hline Vegetable & 21 & & & \\
\hline Area (ha) & & 0.8 & 0.04 & 2.8 \\
\hline la/year) & & 25.0 & 0.06 & 162 \\
\hline 000 bat & & 200.3 & 3.6 & $1,235.3$ \\
\hline Labor (man days/ha) & & 682 & 232 & 1322 \\
\hline Shrimp & 16 & & & \\
\hline Area (ha) & & 1.1 & 0.2 & 6.0 \\
\hline Yield & & 6.6 & 0.4 & 18.8 \\
\hline Total & & $1,398.8$ & 112.0 & $3,712.5$ \\
\hline Labor (man days/ha) & & 292 & 4 & 1138 \\
\hline$\underline{\text { Fish }}$ & 30 & & & \\
\hline Area & & 2.0 & 0.04 & 13.3 \\
\hline Yield & & 10.8 & 0.12 & 96.0 \\
\hline ha/year) & & 286.3 & 2.4 & $2,880.0$ \\
\hline Labor (man days/ha) & & 150 & 3 & 739 \\
\hline Fruit & 30 & & & \\
\hline$\overline{\text { Area }}$ & & 0.8 & 0.1 & 4.7 \\
\hline Yield (t/ha & & 5.9 & 0.1 & 53.6 \\
\hline Total revenue (,000 bath/ha/ye & & 110.5 & 0.94 & 972.0 \\
\hline Labor (man days/ha) & & 161 & 6 & 669 \\
\hline
\end{tabular}

Source: author's survey.

Note : ${ }^{a}$ number of farmers surveyed. 
Table 4 - Average quantities of nutrients used in rice, vegetable and fruit production

Unit: kg/ha/year

\begin{tabular}{lrrrrrr} 
& \multicolumn{2}{c}{ Nitrogen } & \multicolumn{2}{c}{ Phosphorus } & \multicolumn{2}{c}{ Potassium } \\
\cline { 2 - 7 } & Mean & CV & Mean & CV & Mean & CV \\
\hline Rice & 163 & 0.38 & 99 & 0.49 & 8 & 3.64 \\
Fruits & 68 & 0.96 & 79 & 0.90 & 65 & 1.04 \\
Vegetables & 278 & 0.71 & 237 & 0.90 & 212 & 1.12 \\
\hline \multicolumn{2}{l}{ Source: author's survey } & & & & &
\end{tabular}

Table 5 - Average costs per activity

Unit: ('000 bath/ha/year)

\begin{tabular}{lrrrrrrrrrr} 
& \multicolumn{2}{c}{ Rice } & \multicolumn{2}{c}{ Vegetables } & \multicolumn{2}{c}{ Shrimp } & \multicolumn{2}{c}{ Fish } & \multicolumn{2}{c}{ Fruit } \\
\hline & costs & $\%$ & costs & $\%$ & costs & $\%$ & costs & $\%$ & costs & $\%$ \\
\hline Juveniles & 1.9 & 100 & 5.6 & 14 & 121.2 & 94 & 11.4 & $96 \mathrm{a}$ & & \\
Fuel & 2.5 & 100 & 5.2 & 62 & 10.0 & 75 & 1.4 & 79 & 4.2 & 63 \\
Machine rental & 2.3 & 63 & 2.3 & 10 & 24.2 & 69 & 6.1 & 29 & 0.8 & 4 \\
Food/Fertilizers & 5.6 & 100 & 23.9 & 81 & 329.5 & 88 & 92.4 & 50 & 20.7 & 83 \\
Herbicide & 1.3 & 97 & 1.8 & 43 & 0.1 & 6 & 1.3 & 33 & 3.8 & 58 \\
Pesticide & 1.5 & 93 & 16.3 & 71 & 156.1 & 50 & 4.6 & 17 & 13.3 & 58 \\
Organic & & & & & & & 25.7 & 46 & & \\
material & & & 7.4 & 33 & 0.1 & 19 & & & 1.0 & 13 \\
Transportation & 0.8 & 47 & 1.0 & 19 & 0.6 & 6 & 0.3 & 17 & & \\
Labor & 2.9 & 13 & 12.5 & 19 & 9.0 & 13 & 3.4 & 4 & 7.8 & 13 \\
\hline Total & 19.1 & & 79.6 & & 665.0 & & 153.3 & & 52.2 & \\
\hline
\end{tabular}

Source: author's survey.

Note : ${ }^{a}$ percentage of farmers who reported using the input.

Table 6 - Income calculation for the main crops

\begin{tabular}{lrrrrr} 
& Rice & Vegetables & Shrimp & Fish & Fruit \\
\cline { 2 - 6 } Unit: (,000 baht/ha/year) & 39.6 & 200.3 & $1,398.8$ & 286.3 & 110.5 \\
\hline Total revenue & 19.1 & 79.6 & 665.0 & 153.3 & 52.2 \\
Input cost & 23.5 & 120.8 & 741.7 & 136.4 & 58.5 \\
Total value added & 2.0 & 0.4 & 4.9 & 3.7 & 6.4 \\
Non-crop-specific input costs & & & & & 0.1 \\
Proportional depreciation & 21.6 & 120.4 & 736.8 & 132.7 & 52.0 \\
Income & 10.5 & 6.0 & 15.2 & 8.3 & 3.6 \\
Non-proportional depreciation & 2.9 & 3.3 & 2.0 & 2.9 & 2.8 \\
Number of family workers/ha & 3.6 & 1.8 & 7.6 & 2.9 & 1.3 \\
Non-proportional depreciation/family worker & & & & &
\end{tabular}


Table 7 - Summary of main economic results



Table 8 - Cost of water pollution for the farmers

Unit: (baht/ha/year)

\begin{tabular}{lrcrrc}
\hline Crop & Equipment* & $\begin{array}{c}\text { Gas \& } \\
\text { Chemicals }\end{array}$ & Losses & Total & $\begin{array}{c}\text { Share of } \\
\text { total costs }\end{array}$ \\
\hline Vegetables & 800 & 1,000 & - & 1,800 & $1.2 \%$ \\
Shrimp & 4,500 & 8,000 & 30,000 & 42,500 & $3.1 \%$ \\
Fish & - & 1,100 & 8,400 & 9,500 & $7.1 \%$ \\
\hline
\end{tabular}

Source: author's survey.

* ponds and pumps used to decant and clean the water.

Table 9 - Changes in the net income per family worker when water pollution is taken into account

\begin{tabular}{lll}
\hline $\mathrm{NIFW}_{\text {vegetable }}=120.4 \cdot\left(\frac{\mathrm{S}}{\mathrm{FW}}\right)-1.8$ & $\Rightarrow \mathrm{NIFW}_{\text {vegeable }}=119.4 \cdot\left(\frac{\mathrm{S}}{\mathrm{FW}}\right)-2.0$ \\
\hline $\mathrm{NIFW}_{\text {shrimp }}=736,8 \cdot\left(\frac{\mathrm{S}}{\mathrm{FW}}\right)-7.6$ & $\Rightarrow$ & $\mathrm{NIFW}_{\text {shrimp }}=698.9 \cdot\left(\frac{\mathrm{S}}{\mathrm{FW}}\right)-8.1$ \\
\hline $\mathrm{NIFW}_{\text {tish }}=132.7 \cdot\left(\frac{\mathrm{S}}{\mathrm{FW}}\right)-2.9 \quad \Rightarrow \quad \mathrm{NIFW}_{\text {fish }}=123.2 \cdot\left(\frac{\mathrm{S}}{\mathrm{FW}}\right)-2.9$ \\
\hline
\end{tabular}

Table 10 - Main results of the water survey

\begin{tabular}{lc}
\hline & $\begin{array}{c}\text { No. of } \\
\text { farmers }\end{array}$ \\
\hline The water from the canal is clean & 3 \\
Water pollution does not create any problems on the farm & 3 \\
Water pollution creates problems on the farm & 17 \\
- Farmer wants to pay for clean water & 14 \\
- Farmer refuses to pay for clean water & 3 \\
\hline Total & 23 \\
\hline Source: author's survey.
\end{tabular}


Table 11 - Use of nutrients, herbicides and pesticides

Unit: kg/ha/year

\begin{tabular}{lrrrrr}
\hline & Organic material & Fertilizers & Herbicides & Pesticide & Yield \\
\hline Rice & 436 & 270 & 2 & 6 & 10,768 \\
Vegetable & 5,151 & 728 & 6 & 18 & 16,149 \\
Fruit & 3,634 & 213 & 16 & 11 & 5,814 \\
\hline
\end{tabular}

Source: author's survey.

Note: in this table, some yields may be slightly different from those of Table 3 because they were not calculated on exactly the same subset of farmers (missing data).

Table 12 - Summary of results

\begin{tabular}{|c|c|c|c|c|c|c|c|c|}
\hline & Scenario & $\begin{array}{c}\text { Income } \\
\text { (baht/ha/year) }\end{array}$ & $\begin{array}{l}\text { Average } \\
\text { surface } \\
\text { (ha) }\end{array}$ & $\begin{array}{c}\text { Number of } \\
\text { family } \\
\text { workers }\end{array}$ & S/FW & NPD/FW & NIFW & $\begin{array}{c}\text { Difference } \\
\text { (I-II) } \\
\text { (baht/ha/year) }\end{array}$ \\
\hline \multirow[t]{2}{*}{ Vegetable } & I & 120,372 & 0.80 & 3.3 & 0,2 & 1,851 & 27,330 & \multirow{2}{*}{-424} \\
\hline & II & 119,410 & 0.80 & 3.3 & 0,2 & 2,042 & 29,906 & \\
\hline \multirow[t]{2}{*}{ Shrimp } & I & 736,827 & 1.10 & 2.0 & 0,6 & 7,608 & 397,647 & \multirow{2}{*}{ - 21,289 } \\
\hline & II & 698,938 & 1.10 & 2.0 & 0,6 & 8,058 & 376,358 & \\
\hline \multirow[t]{2}{*}{ Fish } & I & 132,722 & 2.00 & 2.9 & 0,7 & 2,911 & 88,621 & \multirow{2}{*}{$-6,516$} \\
\hline & II & 123,274 & 2.00 & 2.9 & 0,7 & 2,911 & 82,105 & \\
\hline
\end{tabular}

Source: author's survey.

Map 1 - Location of survey areas

\section{Research Areas}

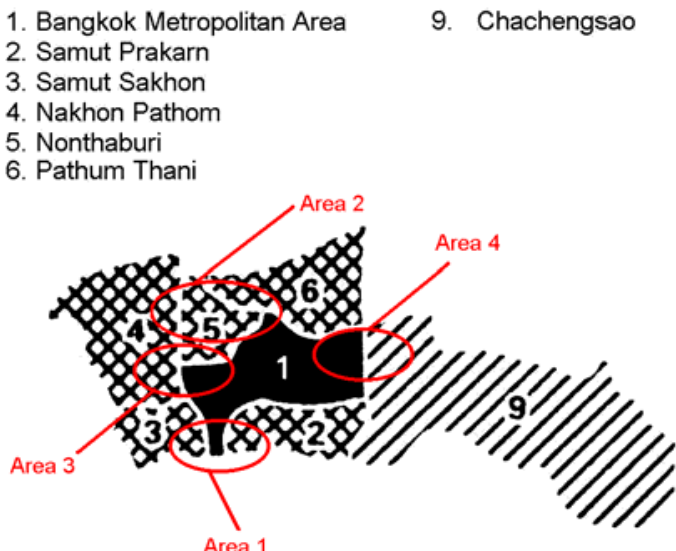

Source : Dixon, 1999 and surveys. 
Figure 1 - Use of fertilizers and yield: rice

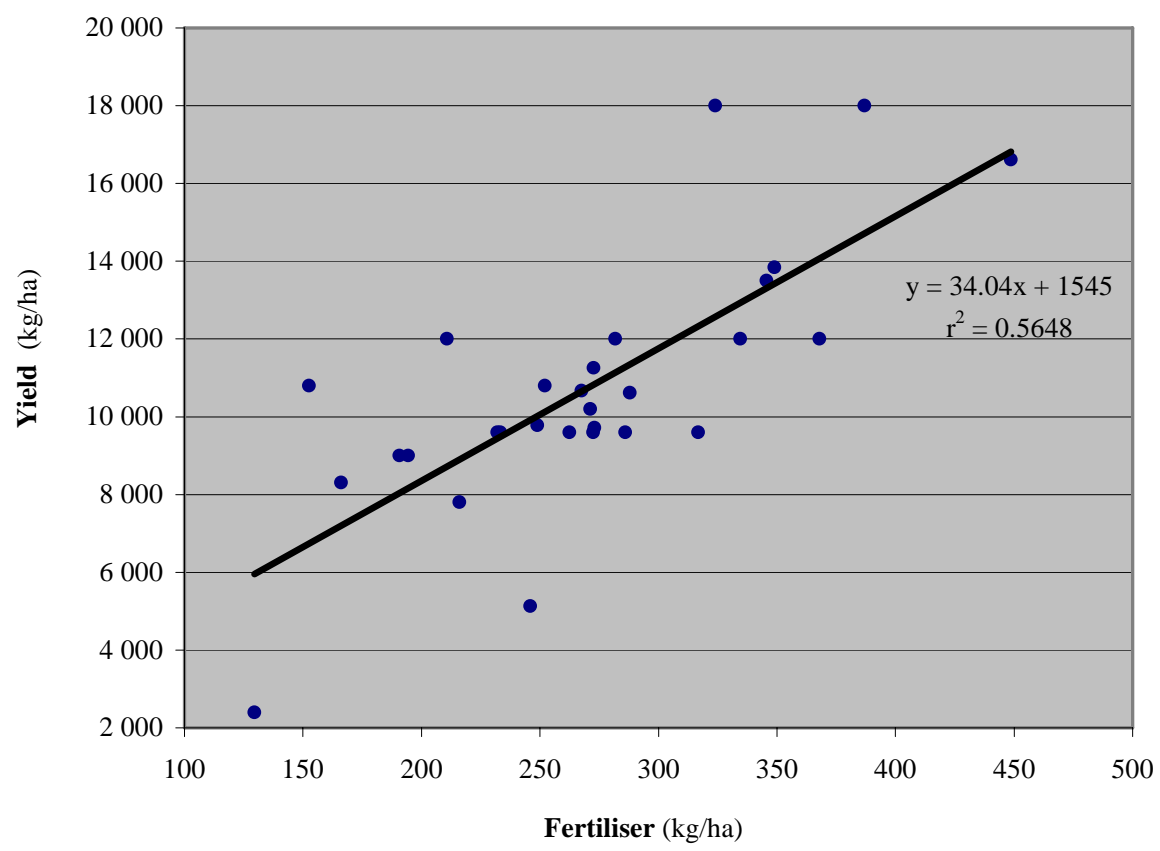

Source: Author's survey. 
Figure 2 - Use of fertilizers and yield: fruit

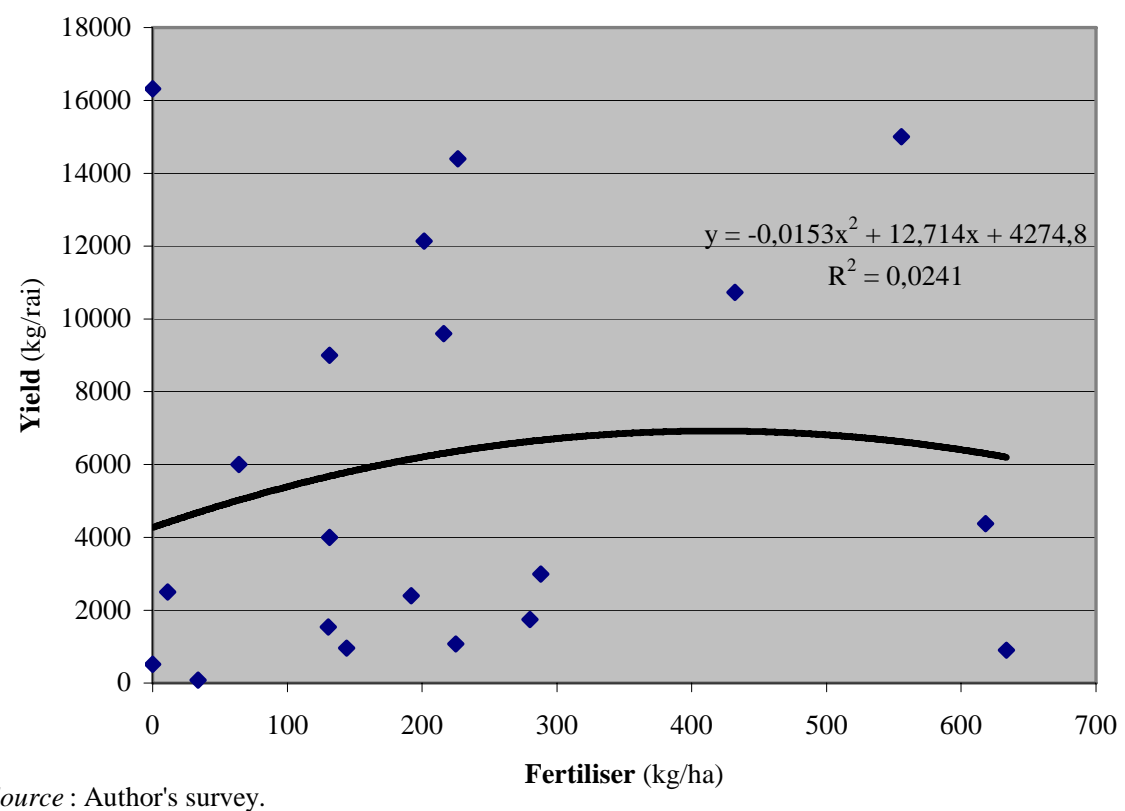

Source : Author's survey.

Figure 3 - Use of pesticides and yield: vegetables

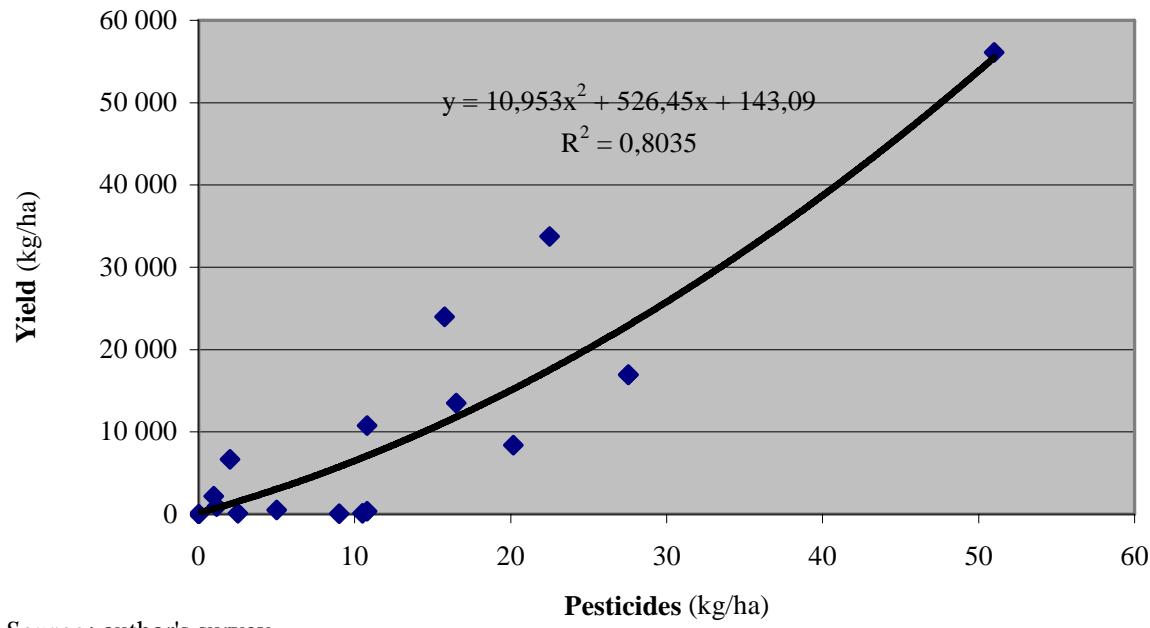

Source : author's survey. 